https://doi.org/10.31470/2706-7904-2020-15-171-175

\title{
МЕТОДОЛОГІЧНІ АСПЕКТИ ДОСЛІДЖЕННЯ ПАНДЕМІЧНОГО ОБРАЗУ СВITУ
}

\section{Methodological Aspects of the Research of the Pandemic Image of the World}

\author{
Olga Lozova \\ DSc.in Psychology, Professor \\ Borys Grinchenko Kyiv University (Ukraine) \\ o.lozova@kubg.edu.ua \\ https://orcid.org/0000-0002-3549-195X
}

\section{Olga Drobot}

DSc.in Psychology, Professor

National Aviation University (Ukraine)

piterkiev@gmail.com

https://orcid.org/0000-0001-5999-7632

\begin{abstract}
Possibilities of research of a pandemic image of the world were theoretically reviewed on the methodological basis of the psychosemantic approach. The pandemic image of the world is positioned as a product and a significant outcome of pandemic consciousness. Pandemic consciousness is a state of mass everyday consciousness that finds its expression in the indirect reflection of everyday life, the essence and content of which is to meet the interests and needs of a given society related to physical and economic survival during a mass pandemic. It is concluded that the content of the pandemic image of the world is formed by activating the following sociopsychological phenomena, mechanisms and coping strategies: stereotyping of mass consciousness, escape into denial, avoidance of an unfavourable reality, infodemia, magical thinking, revival of conspiracy theories and enemy archetypes, creation of new simulacra, increasing alarmism, anxiety about the near future, the search for new meanings of life.
\end{abstract}

Key words: pandemic image of the world; pandemic consciousness.

\section{Вступ \\ Introduction}

Образ світу, ця сукупність сформованих у свідомості людини реальних або уявних аспектів сприйманих нею в навколишньому середовищі об’єктів, - поняття багатогранне і дотичне до різних галузей психології. Образ світу, що потерпає від 
пандемічної хвороби, - пандемічний образ світу, - заслуговує на особливу увагу в силу свої новизни та щоразу інших проявів. Психологічний зміст структурних компонентів пандемічного образу світу досі не було розкрито. Наукова проблема полягає в необхідності дослідження та реконструювання цього образу: принципів структурації його змісту, відтворення в соціокультурному досвіді форм психічного відображення дійсності, властивих масовій свідомості під час пандемії.

Метою дослідження $є$ теоретичний огляд методологічних можливостей дослідження пандемічного образу світу.

\section{Методи та методики дослідження} Methods and Techniques of the Research

Теоретичний огляд можливостей дослідження пандемічного образу світу проведено в межах психосемантики як об'єктної галузі із власною методолого-методичною базою. Застосовано загальнонаукові методи дослідження: аналіз, синтез, узагальнення.

\section{Результати}

\section{Results}

Невіддільність життя індивідів, груп і спільнот від соціального та культурного контексту потребує розгляду генези і трансформацій пандемічного образу світу, представленого в масовій свідомості, у культуро-соціопсихологічному вимірі.

В галузі психосемантики, яка припускає застосування єдиної операціональної моделі категоріальних структур індивідуальної й суспільної свідомості, науковий інтерес являє собою реконструкція образу світу, властивого пандемічній свідомості, та моделюваня семантичних просторів пандемічної свідомості. Психосемантику розглядаємо в якості методології об’єктивованого виміру суб'єктивного змісту пандемічної свідомості спільноти та моделювання системи індивідуальних i колективних значень, що поширені в ній.

У теорії психосемантики спираємось на два постулати О.М. Леонтьєва. Перший: побудова образу світу є активним процесом, істинною роботою свідомості. Другий стосується співвіднесення образу світу зі смисловою сферою особистості, за якого компонентам образу світу надається особистісно-смисловий відтінок. В обох випадках образ світу не є безвідносним до потреб, мотивів, установок суб'єкта, оскільки свідомість не самодостатня, а обслуговує буття і життєві процеси, які здійснюють реалізацію цих мотивів, установок (Леонтьев, 1983). 
Пандемічний образ світу $\epsilon$ продуктом i значеннєвим результатом функціонування пандемічної свідомості, в силу чого може розглядатись як у діахронічному плані (соціогенез), так і в плані становлення свідомості людини в онтогенезі (Лозова, 2014). При цьому варто враховувати, що образ світу усвідомлюється членами суспільства частково і фрагментарно: розрізнені елементи образу світу присутні у свідомості індивіда як фрагменти, що не цілком стикуються між собою. Проводимо аналогію з етнічною свідомістю, в межах якої С.В. Лурьє пояснює цей феномен дією основної функції культури - функції психологічного захисту. Свідомістю фіксується не впорядкована система уявлень, спільних із соціокультурним оточенням індивіда, не іiі смисл, а іiі наявність і цілісність (Лурье, 1998). Передбачаємо, що негативні емоції та дезорієнтація в ситуації невизначеності спричинятиме те, що реально не повний та фрагментарний пандемічний образ світу відчуватиметься і трактуватиметься буденною свідомістю суспільства як цілісний саме з причин психічного збереження та захисту.

Пандемічна свідомість - це стан масової буденної свідомості, який знаходить свій вияв в опосередкованому відображенні повсякденного життя, суттю і змістом якого $\epsilon$ задоволення інтересів та потреб соціуму, пов'язаних 3 фізичним та економічним виживанням під час масового захворювання. Так, у когнітивній площині існування пандемічної свідомості спостерігаються явища інфодемії, конспірологічні теорії, магічне мислення, відродження архетипів ворога та змови, пошук нових сенсів, втеча від несприятливої реальності, породження нових симулякрів та посилення алармізму, усвідомлена тривога щодо найближчого майбутнього. Зростає поширеність копінг-стратегій, за допомогою яких пандемічна свідомість захищається від стресу невизначеності: стереотипізації масової свідомості, втеча в заперечення, уникнення несприятливої реальності, поява нових симулякрів (Леонтьев, 2020).

Дослідження пандемічної свідомості припускають розглядати останню в таких наукових контекстах, як медико-епідеміологічний, соціологічний, соціальнопсихологічний та прикладний. Зокрема, у цьому контексті О.В. Дробот було теоретично констатовано, що поняття «соціальне дистанціювання» розглядається в таких аспектах: як соціальний атитюд у когнітивній, емоційній та поведінковій репрезентаціях; як психосоціальна детермінанта стресів; як можлива причина зниження довіри; як копінг-стратегія (Дробот, 2020).

В галузі психосемантики предмет пандемічного образу світу може отримати найрізноманітніші ракурси свого розгляду: знаково-символічна сутність пандемічного образу світу; особливості усвідомлення пандемічного світу представниками різних соціальних груп і спільнот; специфіка переживань з приводу пандемічного світу; ставлення до пандемічної хвороби та не пандемічних захворювань; дослідження 
самоставлення людей, що пережили COVID-19; семантика сприйняття соціального оточення; трансформації особистісного досвіду в умовах пандемії: психосемантика комунікативної гармонійності/дисгармонійності в часи COVID-19 тощо.

Гіпотетично, 3 плином часу масовий образ пандемічного світу може розділитися на докарантинний, карантинний та посткарантинний світ. 3 урахуванням поділу країни на карантинні зони та наявність різних регіональних ментальностей, важливим критерієм для виявлення семантики пандемічного образу світу може стати регіон проживання респондентів.

\section{Висновки \\ Conclusions}

Таким чином, на методологічній базі психосемантичного підходу було реалізовано теоретичний огляд можливостей дослідження пандемічного образу світу. Пандемічний образ світу позиціоновано як продукт i значеннєвий результат функціонування пандемічної свідомості. Пандемічна свідомість - це стан масової буденної свідомості, який знаходить свій вияв в опосередкованому відображенні повсякденного життя, суттю і змістом якого $є$ задоволення інтересів та потреб соціуму, пов'язаних із фізичним та економічним виживанням під час масового захворювання. Зроблено висновок про те, що зміст пандемічного образу світу утворюється завдяки активації таких соціально-психологічних явищ, механізмів та копінг-статегій життя: стереотипізація масової свідомості, втеча в заперечення, уникнення несприятливої реальності, інфодемія, магічне мислення, відродження конспірологічних теорій, архетипів ворога та змови, втеча від несприятливої реальності, породження нових симулякрів, посилення алармізму, усвідомлення тривоги щодо найближчого майбутнього, пошук нових сенсів життя.

\section{Література \\ References}

Дробот, О.В. (2020). Предметний аналіз поняття «соціальне дистанціювання» в різних суспільних та наукових контекстах. О.В. Дробот (Відп. ред.), Психологія свідомості: теорія і практика наукових досліджень: тези IV міжнародної науково-практичної конференції (Київ 21.11.2020), (с. 23-27). Київ: Талком.

Леонтьев, А.Н. (1983). Образ мира. Избранные психологические произведения. (Т. 2, с. 251261). Москва: Педагогика.

Леонтьев, Д. А. (2007). Психология смысла: природа, строение и динамика смысловой реальности. Москва: Смысл. 
Psycholinguistics in a Modern World - 2020. Proceedings of the 15th International Scientific and Practical Conference (Pereiaslav-Khmelnytskyi, 22-23 October, 2020)

Леонтьев, Д.А. (2020). Виражи и миражи пандемического сознания. Страхи и надежды человечества. Психология спасет мир? Санкт-Петербургский саммит психологов. 09.07.2020. https://psy.su/feed/8337/

Лозова, О.М. (2014). Синергетична єдність етногенетичних та соціогенетичних елементів змісту свідомості українців. О.М. Лозова (Ред.), Етнопсихологічний вимір Украӥни: семіозис, міфотворчість, ідентичність (с. 4-44). Київ: Інтерсервіс,

Лурье, С.В. (1998). Историческая этнология. Москва: Аспект Пресс. 